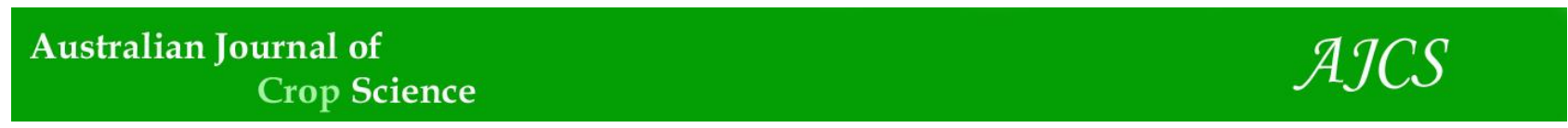

AJCS 15(07):1051-1057 (2021)

ISSN:1835-2707

doi: 10.21475/ajcs.21.15.07.p3172

\title{
Antioxidant enzymes activity in 'Castel Gala' apple trees after the budbreak inducers application
}

\author{
Léo Omar Duarte Marques ${ }^{1}$, Caroline Hernke Thiel ${ }^{2}$, Gabrielle Leivas de Leivas ${ }^{2}$, Sidnei Deuner ${ }^{2}$, Mateus \\ da Silveira Pasa ${ }^{1}$, Flavio Gilberto Herter ${ }^{1}$, Paulo Mello-Farias ${ }^{1}$
}

${ }^{1}$ Federal University of Pelotas - Graduate Program in Agricultural Science - Pelotas, RS, Brazil
${ }^{2}$ Federal University of Pelotas - Graduate Program in Plant Physiology - Pelotas, RS, Brazil

*Corresponding author: leodmq@hotmail.com

\begin{abstract}
Since antioxidant enzymes activity affects the end of dormancy stage, it is important to understand the responses given by antioxidant enzymes and their roles in budbreak induction in temperate fruit trees. This research aimed at evaluating the antioxidant enzymes activity at the end of budbreak stage after the inducers application to 'Castel Gala' apple trees and their performance in budbreak

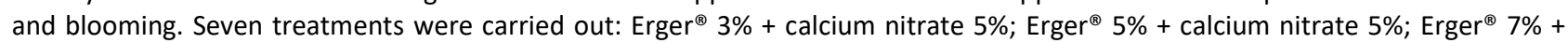
calcium nitrate 5\%; garlic extract (GE) 5\% + mineral oil (MO) 2\%; GE 10\% + MO 2\%; GE $15 \%+$ MO 2\%; and the control. Buds were collected one, four and seven days after the application (DAA) of budbreak inducers, and activity of the following enzymes was determined by: superoxide dismutase (SOD), catalase (CAT) and ascorbate peroxidase (APX). Besides that, hydrogen peroxide was quantified. Percentages of budbreak and blooming were evaluated at $32^{\text {th }}, 40^{\text {th }}, 45^{\text {th }}$ and $52^{\text {th }}$ DAA. The results showed that SOD activity had increased as the dormancy stage reached its end. CAT activity was influenced by the application of budbreak inducers. It decreased significantly throughout the experiment in the most efficient treatment. Percentages of budbreak $(61.85 \%)$ and blooming (25.44\%) showed the highest efficiency in the treatment with Erger $^{\circledR} 7 \%+$ calcium nitrate $5 \%$, which was the inducer with the highest potential in 'Castel Gala' apple trees.
\end{abstract}

Keywords: Malus domestica, catalase, superoxide dismutase, ascorbate peroxidase, hydrogen peroxide, mild winter.

Abbreviations: $\mathrm{H}_{2} \mathrm{O}_{2}$ hydrogen peroxide; $\mathrm{O}_{2}$ oxygen; $\mathrm{SOD}$ _superoxide dismutase; CAT_catalase; APX_ascorbate peroxidase; ROS_reactive oxygen species; DAA_days after application; FM_fresh matter; GE_garlic extract; $\mathrm{CH}_{-}$chill hours $<7.2^{\circ} \mathrm{C}$; cfa_humid subtropical climate with mild winters; TCA_trichloroacetic acid; NBT_nitrotetrazolium; PVPP_polyvinylpolypyrrolidone.

\section{Introduction}

Malus domestica Borkh. apple tree is one of the most popular and widespread fruit trees in the world since it belongs to a temperate species. In fall and winter, it goes through a phase of temporary suspension of visible growth, mainly the buds, called dormancy - and undergoes physiological alterations to withstand adverse conditions (Farrokhi et al., 2011; Pasa et al., 2018). Dormancy length of apple trees depends on the region where they grow and the cultivars, considering that some require more chill hours than others to overcome the dormancy period (Abreu et al., 2018). Thus, when a certain cultivar is implanted in a region where wintry chill accumulation is below the required one, there is an alteration in budbreak and blooming, which affects fruit quality (Pasa et al., 2018).

Use of budbreak inducers increases percentages of budbreak and blooming, besides promoting homogenization of buds phenological stages and, the main budbreak inducer in apple trees is hydrogen cyanamide (Rady and El-Yazal, 2013). However, Santos et al. (2020) found that its high toxicity poses risks to both workers and the environment. These authors also highlighted the urgent need to carry out studies that aim at new alternative products, such as Erger $^{\circledR}$ and garlic extract (GE). The former is a leaf fertilizer based on nitrogen and calcium (Darde et al., 2019). According to Santos et al. (2020), the latter is a compound which is rich in diallyl disulfide and other sulfur compounds that increase production of hydrogen peroxide $\left(\mathrm{H}_{2} \mathrm{O}_{2}\right)$, which is an element that is responsible for budbreak induction.

Inhibition or activation of antioxidant enzymes, gene expression and $\mathrm{H}_{2} \mathrm{O}_{2}$ accumulation are some factors involved in physiological processes (Rady and El-Yazal, 2013; Takemura et al., 2015). Mohamed et al. (2012) have highlighted maximum $\mathrm{H}_{2} \mathrm{O}_{2}$ accumulation as the end of all physiological processes throughout dormancy, and it shows the end of the dormancy stage and the beginning of budbreak. However, there is a complex system of antioxidant enzymes that persists up to the end of dormancy stage, in which certain enzymes either increase or decrease their activities depending on their mechanisms of action - to make buds overcome it (Takemura et al. 2015).

At the end of the dormancy stage, the most important antioxidant enzymes are superoxide dismutase (SOD), catalase (CAT) and ascorbate peroxidase (APX) (Takemura et al., 2015; Cai et al., 2019). SOD is the first line of defense in the plant enzyme system which efficiently decreases concentrations of superoxide anion. $\mathrm{H}_{2} \mathrm{O}_{2}$ is one of the 
products of SOD activity, since the latter is positively correlated to $\mathrm{H}_{2} \mathrm{O}_{2}$ levels, for example high SOD activity corresponds to high $\mathrm{H}_{2} \mathrm{O}_{2}$ levels (Shalimu et al., 2016). SOD has a straight relation with the end of the dormancy stage. According to Hernandez et al. (2021), since its activity increases steadily up to the end of the dormancy stage, it must be studied so as to understand the physiology involved in the transitory process from dormancy to budbreak.

CAT is an antioxidant enzyme that acts after SOD, since it is the main degrader of $\mathrm{H}_{2} \mathrm{O}_{2}$, an element that results from SOD activity. Thus, CAT acts in the second line of defense (Mujahid et al. 2020). However, CAT is most studied enzyme in fruticulture because it degrades $\mathrm{H}_{2} \mathrm{O}_{2}$, which needs to be accumulated to induce budbreak. This enzyme is believed to be antagonistic to the budbreak process and its levels have to be reduced. Some budbreak inducers, such as hydrogen cyanamide, have been sometimes described as CAT inhibitors, considering that knowledge about this enzyme is very important to understand the end of the dormancy process and budbreak induction (Mujahid et al. 2020).

Both APX and CAT take part in the second line of defense in the plant enzyme system. They act on $\mathrm{H}_{2} \mathrm{O}_{2}$ elimination, but at different sites in cells. For instance, since CAT is not found in chloroplasts, APX is in charge of eliminating $\mathrm{H}_{2} \mathrm{O}_{2}$ from these sites. APX also differs from CAT in terms of affinity with $\mathrm{H}_{2} \mathrm{O}_{2}$, for example it has more affinity with $\mathrm{H}_{2} \mathrm{O}_{2}$ than CAT and carries out finer metabolic regulation, thus, eliminating low $\mathrm{H}_{2} \mathrm{O}_{2}$ concentrations (Dousseau et al., 2016; Vuleta et al. 2016). APX activity in budbreak induction has been little studied by comparison with CAT activity. Hernandez et al. (2021) mentioned increase in APX activity in the dormancy process, since it is low at the beginning and high at the end of dormancy. However, in-depth studies are needed to research more about APX activity at the end of the dormancy process because it is known to act on $\mathrm{H}_{2} \mathrm{O}_{2}$, the main element in budbreak induction.

Concomitant studies of these antioxidant enzymes (CAT, SOD and APX) are fundamental because they compose a complex defense system in plants (Cai et al., 2019). Their activities are interconnected, since they aim at protecting plants from damage caused by reactive oxygen species (ROS). Besides that, their variations may show changes in phenological stages (Cai et al., 2019).

This research aimed at evaluating the activity of antioxidant enzymes after the application of budbreak inducers to 'Castel Gala' apple trees grown in a region characterized by the lack of wintry chill and the performance of inducers in budbreak and blooming.

\section{Results}

\section{SOD enzyme Activity}

Results of the analysis of SOD showed an increase in its activity in the period under evaluation (Fig. 1a). In all treatments, the highest enzyme activity was found 7 days after the application (DAA). Treatments did not show any effect on SOD activity at $4^{\text {th }}$ and $7^{\text {th }}$ DAA (Fig. 1b), since they did not differ significantly among them. On the $1^{\text {st }} \mathrm{DAA}$, both the control treatment (T7) and T5 were found to exhibit the lowest activity of SOD (Fig. 1a).

\section{CAT enzyme Activity}

Both treatments T3 and T4 showed significant decrease in CAT activity from the $1^{\text {st }}$ to the $7^{\text {th }}$ DAA, which followed a pattern of behavior (Fig. 1b). In treatments T1, T2 and T5, CAT exhibited oscillation in the period under evaluation, while, in treatments T6 and T7 (control treatment), it showed stability in this time interval.

On the $1^{\text {st }}$ DAA, treatments that included Erger $^{\circledR}$ in their composition showed an increase in CAT activity, for example the higher its concentration is, the more enzyme activity was observed. On the $7^{\text {th }}$ DAA, plants had a more stable enzyme defense system through CAT, and all treatments exhibited low CAT activity, with no significant differences among them.

\section{APX enzyme Activity}

APX activity did not exhibit a defined pattern (neither a decrease nor an increase). Six out of seven treatments did not show any significant difference in the period under evaluation (Fig. 2a). Regarding the treatments application, differences were found between the $1^{\text {st }}$ and the $4^{\text {th }}$ DAA. Treatments did not differ significantly among them on the $7^{\text {th }}$ DAA.

\section{$\mathrm{H}_{2} \mathrm{O}_{2}$ levels}

$\mathrm{H}_{2} \mathrm{O}_{2}$ levels showed variation between 1.87 and $2.75 \mu \mathrm{mol} \mathrm{g}^{-1}$ $\mathrm{FM}$ in the period under evaluation. There were no significant differences in treatments related to the period under evaluation (Fig. 2b).

\section{Percentages of budbreak and blooming}

Budbreak inducer T3 (Erger ${ }^{\circledR} 7 \%$ + calcium nitrate 5\%) promoted the highest final budbreak percentage, for example $61.85 \%$ (Fig. 3a), which was 3 -fold the percentage exhibited by the control treatment. T3 showed budbreak percentage around $60 \%$ in the $40^{\text {th }} \mathrm{DAA}$, and it means that it had precocious high budbreak percentage.

Blooming results were also better after the treatment composed of Erger $^{\circledR} 7 \%$ + calcium nitrate $5 \%$. Blooming percentage was $25.44 \%$ (Fig. $3 \mathrm{~b}$ ), while the control treatment exhibited $3.14 \%$. GE and $\operatorname{Erger}^{\circledR}$ at other concentrations led to around $20 \%$ blooming.

\section{Discussion}

SOD is the first line of defense in the plant enzyme system, since it removes ROS from cells (Xing-Liang et al., 2017). According to Azarabadi et al. (2017), SOD converts superoxide anion into $\mathrm{H}_{2} \mathrm{O}_{2}$ and $\mathrm{O}_{2}$, a fact that means that an increase in its activity is favorable to budbreak induction. The authors stated that one of the products of SOD activity is $\mathrm{H}_{2} \mathrm{O}_{2}$, an element that needs to be accumulated so that the dormancy stage can finish and budbreak can be induced. According to Cai et al. (2019), an increase in levels of SOD activity is an indicator of the end of dormancy, and plant metabolism is accelerating. The authors reported an increase in SOD activity in their cherry trees (Prunus avium) research.

Some treatments, such as T1 and T2, activated plant metabolism faster on the $1^{\text {st }}$ DAA. SOD activity was higher when these treatments were applied, when comparing with the control one. According to Cai et al. (2019), an increase in SOD activity is related to a rise in metabolism, promoting an activation of the defense system as a result of ROS activity (mainly superoxide anion). All treatments exhibited an enhance in SOD activity throughout the evaluation. Therefore, an increase in levels of SOD activity is believed to result from the proximity of the end of winter, which coincides with the end of the dormancy stage. Some earlier buds were in the transition from stage $B$ - known as silver tip - to stage $C-$ known as green tip - on the $7^{\text {th }}$ DAA. Thus, there was some evidence that dormancy was reaching its end, 


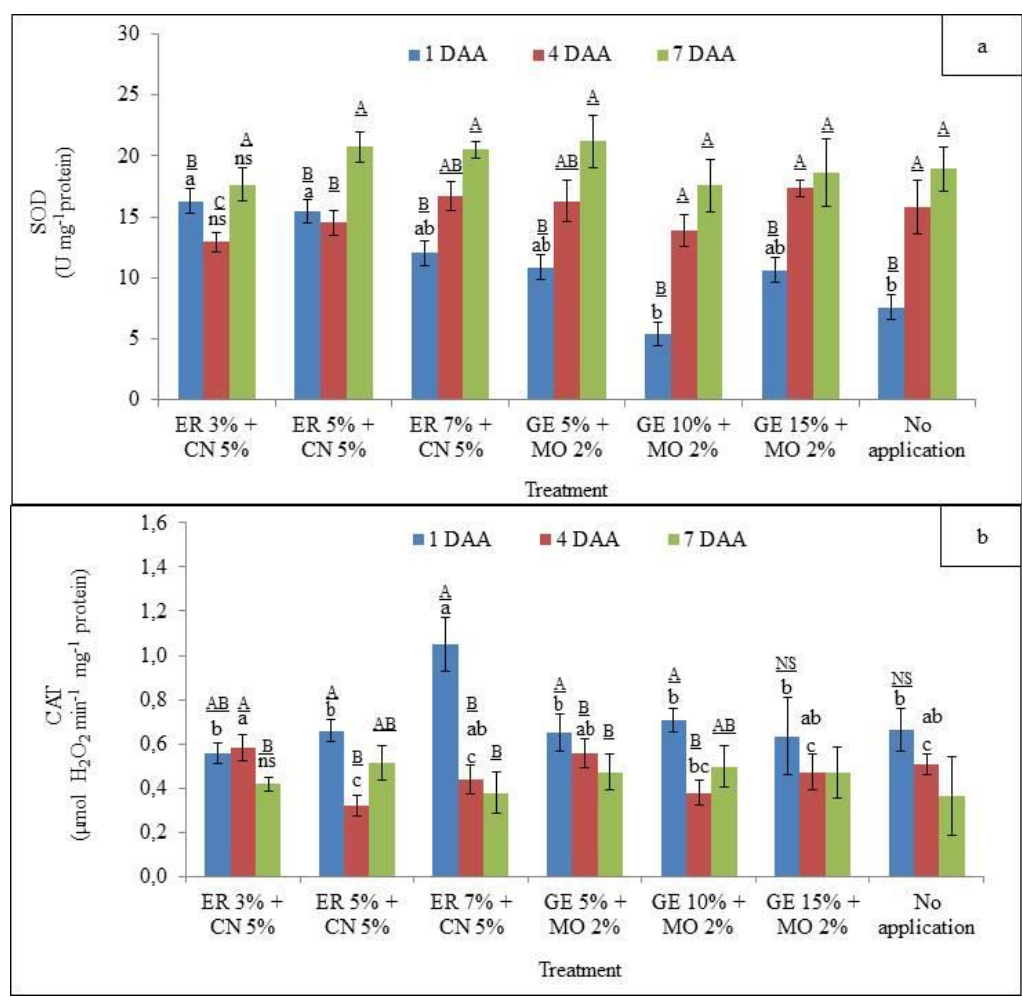

Fig 1. Activities of antioxidant enzymes superoxide dismutase (SOD) and catalase (CAT) at $1^{\text {st }}, 4^{\text {th }}$ and $7^{\text {th }}$ DAA (days after application) in 'Castel Gala' apple trees. ER: Erger ${ }^{\circledR}$; CN: calcium nitrate; GE: garlic extract; MO: mineral oil; and No Application (control treatment). * Means followed by the same low case letters do not differ statistically regarding the comparison among budbreak inducers within each collection date (DAA), for example within the same bar color. Means followed by the same uppercase letters do not differ statistically concerning the comparison among collection dates (DAA), within each budbreak inducer treatment, according to Duncan's test at $5 \%$ probability. ${ }^{N S}$ (ns) non-significant statistical difference at $5 \%$ probability.

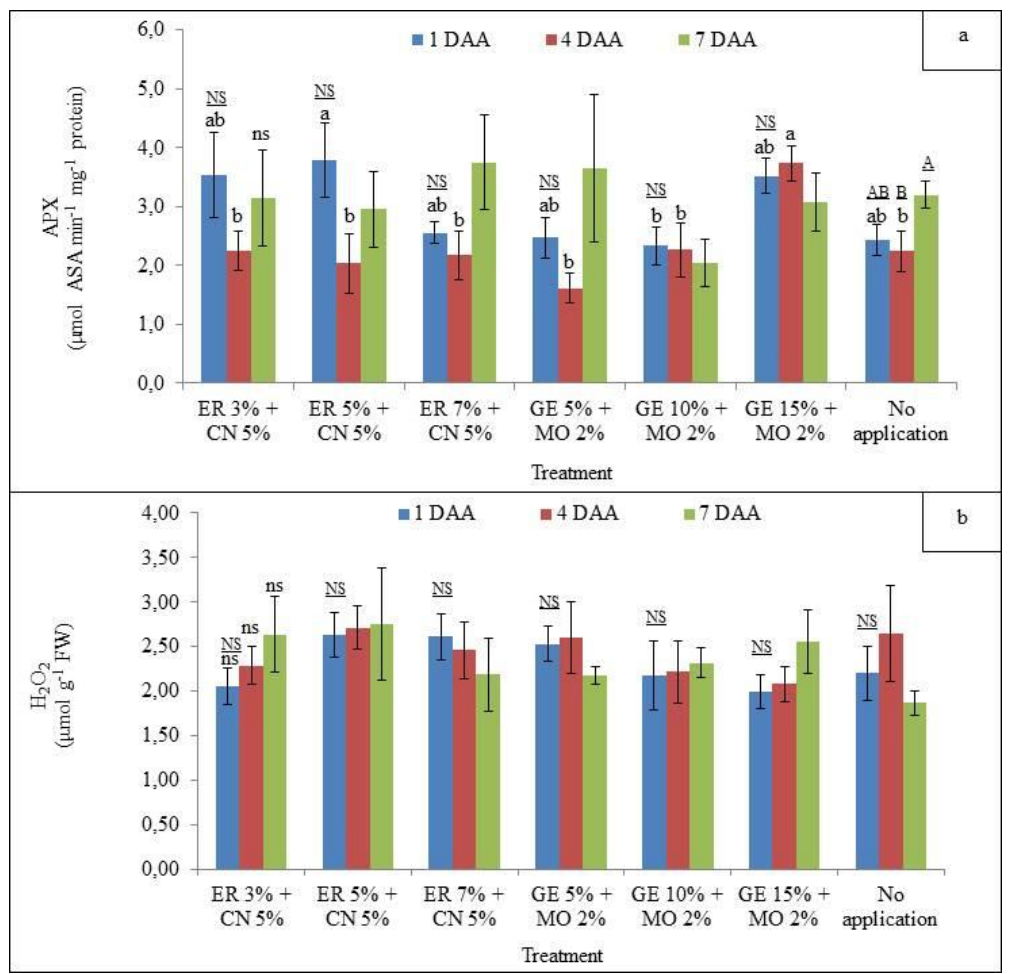

Fig 2. Activity of antioxidant enzyme ascorbate peroxidase (APX) and content of hydrogen peroxide at $1^{\text {st }}, 4^{\text {th }}$ and $7^{\text {th }}$ DAA (days after application) in 'Castel Gala' apple trees. ER: $\operatorname{Erger}^{\circledR}$; CN: calcium nitrate; GE: garlic extract; MO: mineral oil; and No Application (control treatment). * Means followed by the same low case letters do not differ statistically regarding the comparison among budbreak inducers within each collection date (DAA), for example within the same bar color. Means followed by the same uppercase letters do not differ statistically concerning the comparison among collection dates (DAA), within each budbreak inducer treatment, according to the Duncan's test at $5 \%$ probability. NS (ns) non-significant statistical difference at $5 \%$ probability. 


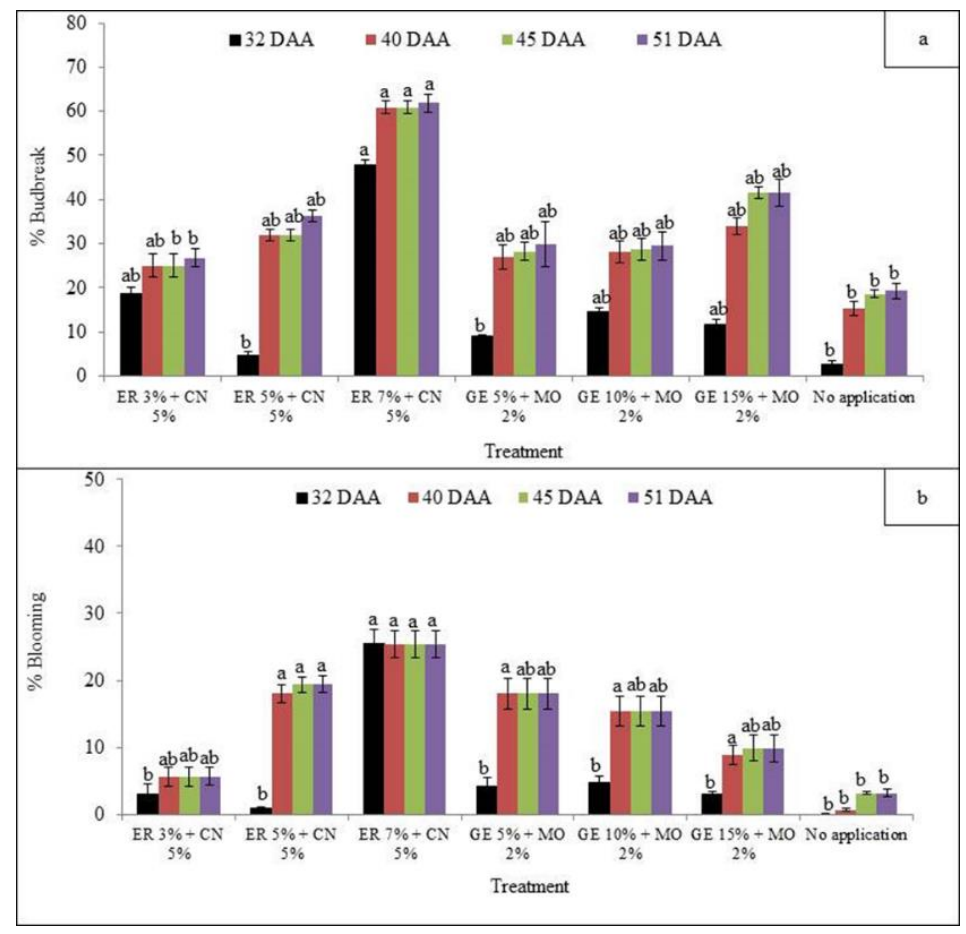

Fig 3. Percentages of budbreak and blooming in 'Castel Gala' apple trees after application of different budbreak inducers at $32^{\text {th }}, 40$ th, $45^{\text {th }}$ and $51^{\text {th }}$ days after application (DAA). ER: Erger ${ }^{\circledR} ; \mathrm{CN}$ : calcium nitrate; GE: garlic extract; MO: mineral oil; and No Application (control treatment). * Means followed by the same letter do not differ statistically regarding the comparison among budbreak inducers within each collection date (DAA), for example within the same bar color by the Duncan's test at $5 \%$ probability.

having no relation between the increase of SOD activity and budbreak inducers application. This statement is supported by the results of the control treatment, since it exhibited an increase in SOD activity, which also happened to the other treatments.

According to Takemura et al. (2015), CAT tends to decrease its activity as the dormancy stage gets to its end and budbreak is induced, and a decline in CAT activity was a sign of the end of the dormancy stage. A decrease in CAT activity is fundamental at the end of dormancy, since it is responsible for degrading $\mathrm{H}_{2} \mathrm{O}_{2}$ to water and molecular oxygen (Pérez and Lira, 2005). $\mathrm{H}_{2} \mathrm{O}_{2}$ accumulation in plant tissues is one of the requirements to induce budbreak because it generates oxidative stress. It acts as a chemical sign to activate genes, thus indicating the end of dormancy and inducing budbreak (Takemura et al., 2015). When CAT activity is high, there is no $\mathrm{H}_{2} \mathrm{O}_{2}$ accumulation in plant tissues, and as a result, plants keep dormant (Pérez and Lira, 2005).

Cai et al. (2019) stated that an efficient budbreak inducer should reduce CAT activity, when comparing with the control treatment. Pérez and Lira (2005) also attributed high efficiency to hydrogen cyanamide, when contrasting with other products, because of its high capacity to decrease CAT activity within the buds. Hence, the treatment that led to the highest percentages of budbreak and blooming (T3) was the one that, together with $\mathrm{T} 4$, exhibited the capacity to decrease CAT activity in the period under evaluation (from $1^{\text {st }}$ to $7^{\text {th }}$ DAA). It may be an evidence of T3 success.

An increase in the activity - proportional to a rise in Erger $^{\circledR}$ concentration on the $1^{\text {st }} \mathrm{DAA}$ - may show that the higher the dose is, the higher the plant stresses. It makes plants activate their defense systems by CAT. This fact leads to the belief that T3 induces high stress to plants right after application. However, the treatment is capable of decreasing CAT activity significantly. Finally, it tends to result in high percentages of budbreak and blooming.

Concerning APX, differences in its activity found in treatments between the $1^{\text {st }}$ and $4^{\text {th }}$ DAA do not contribute with any relevant information. It could show changes in plant metabolism resulting from the end of the dormancy stage. Therefore, these results do not provide information that associates APX activity with the end of the dormancy stage. APX, which is the second line of defense in the plant enzyme system, acts on certain elements, such as $\mathrm{H}_{2} \mathrm{O}_{2}$ and CAT, but in different compartments (Azarabadi et al., 2017). According to Cai et al. (2019), APX exhibits low activity throughout the dormancy period, and the closer to the end of dormancy, the higher its activity is. Takemura et al. (2015) stated that the highest APX activity takes place after the peak of $\mathrm{H}_{2} \mathrm{O}_{2}$ accumulation, so as to eliminate its excess and avoid cell damage. The hypothesis is that there was no peak of $\mathrm{H}_{2} \mathrm{O}_{2}$ accumulation within buds when material was collected to carry out this research. If so, the plant had neither activated its defense mechanism nor increased APX activity yet. SOD, which is the first line of defense in the plant antioxidant system, still exhibited an increase in its activity at $7^{\text {th }}$ DAA. Thus, in agreement with the literature, there may have happened an increase in APX activity (second line of defense) after the $7^{\text {th }}$ day.

Results of $\mathrm{H}_{2} \mathrm{O}_{2}$ found by this research are not definite since there is no clear pattern related to $\mathrm{H}_{2} \mathrm{O}_{2}$ levels observed by different treatments and dates. The hypothesis is that the levels were read on days that were close to those on which budbreak inducers were applied. Darde et al. (2019) applied Erger $^{\circledR}$ to 'Eva' apple trees at concentrations that ranged from $3 \%$ to $5 \%+$ calcium nitrate and found $\mathrm{H}_{2} \mathrm{O}_{2}$ levels below 2.00 $\mu \mathrm{mol} \mathrm{g}^{-1} \mathrm{FM}$ on the $5^{\text {th }}$ DAA. No relation was found between the results and the end of the dormancy stage when the study ended. 
The hypothesis that the collection was close to the application is supported by the fact that CAT activity was decreasing. As mentioned before, CAT activity needs to be low so that $\mathrm{H}_{2} \mathrm{O}_{2}$ levels can increase. To perceive any increase, the minimum CAT activity should be known. Rady and El-Yazal (2013) studied 'Anna' apple trees and analyzed $\mathrm{H}_{2} \mathrm{O}_{2}$ levels throughout several collections of buds for a long period after the application of budbreak inducers. They observed that the peak of $\mathrm{H}_{2} \mathrm{O}_{2}$ took place at $40^{\text {th }}$ DAA of budbreak inducers, for example closer to budbreak. These authors also reported values of $4.55 \mu \mathrm{mol} \mathrm{g}^{-1} \mathrm{FM}$ in the control and about $7.00 \mu \mathrm{mol}$ $\mathrm{g}^{-1} \mathrm{FM}$ in the treatment with hydrogen cyanamide at $40^{\text {th }} \mathrm{DAA}$. Their values are much higher than the ones found by this study.

El-Yazal e Rady (2014) studied 'Anna' apple trees and found the peak of $\mathrm{H}_{2} \mathrm{O}_{2}$ accumulation close to $40^{\text {th }}$ DAA and levels were close to $7.00 \mu \mathrm{mol} \mathrm{g}{ }^{-1} \mathrm{FM}$. According to Abreu et al. (2018), 'Castel Gala' apple trees need about $400 \mathrm{CHs}<7.2^{\circ} \mathrm{C}$, for example this cultivar requires little cold, just like 'Anna' and 'Eva', studies here previously mentioned. Thus, the three cultivars may react similarly levels in terms of $\mathrm{H}_{2} \mathrm{O}_{2}$. If collections had been carried out on the $7^{\text {th }}$ day or after that, $\mathrm{H}_{2} \mathrm{O}_{2}$ behavior in 'Castel Gala' apple trees at the end of dormancy could have been better understood.

High efficiency of T3 $\left(\right.$ Erger $^{\circledR} 7 \%+$ calcium nitrate $5 \%$ ) in final budbreak percentages (61.85\%) was found, when comparing with previous studies. Abreu et al. (2018) studied the effect of budbreak inducers on 'Castel Gala' apple trees and found the best results $(49.91 \%)$ in the treatment with hydrogen cyanamide $1.5 \%+$ mineral oil (MO) $3 \%$. They also studied the effect of $\operatorname{Erger}^{\circledR}+$ calcium nitrate at 3\% and $5 \%$ and reached budbreak percentages of $42.91 \%$ and $41.79 \%$, respectively. Margoti et al. (2020) studied different doses of $\operatorname{Erger}^{\circledR}(3 \%$, $5 \%$ and $7 \%$ ) associated with calcium nitrate in 'Eva' apple trees budbreak induction. They found the highest budbreak percentages, as this study, at the highest dose (7\%), and apple trees exhibited budbreak percentage of $51.90 \%$. Results of this research have shown that new studies of the treatment (Erger ${ }^{\circledR} 7 \%$ + calcium nitrate $5 \%$ ) must be carried out, since it is a potential budbreak inducer which reached better results than a study of the same cultivar conducted by Abreu et al. (2018). Results of another cultivar reported by Margoti et al. (2020) show that $\operatorname{Erger}^{\circledR} 7 \%$ associated with calcium nitrate reaches better results than other concentrations of the product. Blooming percentage was not different, for example T3 (Erger ${ }^{\circledR} 7 \%+$ calcium nitrate $5 \%$ ) exhibited the best results and reinforced results of budbreak. It shows that Erger ${ }^{\circledR} 7 \%+$ calcium nitrate $5 \%$ is a potential budbreak inducer that should be included in further studies as a treatment to induce budbreak in 'Castel Gala' apple trees because it stands out in this research.

\section{Materials and methods}

\section{Plant material}

The experiment was carried out in 8-year-old 'Castel Gala' apple trees grafted on 'Marubakaido' (rootstock) with 'M-9' filter (interstem), conducted on a central-leader system. Spacing was $5.0 \mathrm{~m} \times 0.9 \mathrm{~m}$ (rows $\times$ plants).

\section{Study area and climate}

The orchard is located in Capão do Leão, Rio Grande do Sul (RS) state, Brazil (latitude 31 $52^{\prime} \mathrm{S}$, longitude 52 $21^{\prime} \mathrm{W}$ and altitude of $13 \mathrm{~m})$. In the Köppen-Geiger classification, the climate in the region is humid subtropical with mild winters (cfa). Annual means are $1367 \mathrm{~mm}$ (rainfall), $17.8^{\circ} \mathrm{C}$ (temperature), $80.7 \%$ (relative air humidity in 307 chill hours (CHs) below $7.2^{\circ} \mathrm{C}$ ) from April to September. The experiment was carried out in the 2019/2020 development cycle. CHs below $7.2^{\circ} \mathrm{C}$ were calculated from the beginning of April to the end of August ( $275 \mathrm{CHs}$ ) and September $(318 \mathrm{CHs})$.

\section{Budbreak inducers}

Budbreak inducers were composed of different concentrations of $\operatorname{Erger}^{\circledR}$ (a mineral leaf fertilizer based on nitrogen and calcium, from Valagro do Brasil Ltda.) together with calcium nitrate, GE associated with Assist ${ }^{\circledR} \mathrm{MO}(750 \mathrm{~mL}$ $\mathrm{L}^{-1} \mathrm{MO}, \mathrm{Basf} \mathrm{S} . \mathrm{A}$.) and the control treatment (with no product application).

\section{Experimental design}

The experiment had a randomized block design with four replicates, and every plant corresponded to a replicate. Border plants were kept in order to prevent crosscontamination from taking place, and seven treatments were applied: T1 $\left(\right.$ Erger $^{\circledR} 3 \%+$ calcium nitrate $\left.5 \%\right)$, T2 $\left(\right.$ Erger $^{\circledR} 5 \%+$ calcium nitrate $5 \%)$, T3 $\left(\right.$ Erger $^{\circledR} 7 \%+$ calcium nitrate $\left.5 \%\right)$, T4 (GE 5\% + MO 2\%), T5 (GE 10\% + MO 2\%), T6 (GE 15\% + MO $2 \%)$ and T7 (with no application - control treatment).

\section{GE preparation and treatment application}

The extract was obtained by cold extraction from peeled bulbs of common white garlic (Allium sativum L.) in a home centrifuge the day before the application. Afterwards, it was filtered through a cloth strainer and stored in plastic bottles, which were wrapped in tin foil up to the application, in the ratio of 3:1 (weight/volume).

Budbreak inducers were applied on August $28^{\text {th }}, 2019$, before $10 \mathrm{am}$, at about $18^{\circ} \mathrm{C}$, with no wind, using a backpack sprayer with a fan-shaped nozzle. The stock was prepared few minutes before the application, and products were diluted to meet requirements of the treatments under investigation. After the application of every treatment, the backpack sprayer was washed with water and neutral soap three times so as to remove any residue from the previous treatment. Stocks of every treatment were sprayed on the aerial parts of plants to the drip point.

\section{Material collection for enzymes analyses}

Terminal buds were collected from branches and spurs to carry out analyses of enzyme activity and $\mathrm{H}_{2} \mathrm{O}_{2}$. They were collected at $1^{\text {st }}, 4^{\text {th }}$ and $7^{\text {th }}$ DAA, and collections were called 1 , 2 and 3 , respectively. About $300 \mathrm{mg}$ of plant material was collected to conduct the analysis of enzyme activity, while the same amount was collected to carry out the $\mathrm{H}_{2} \mathrm{O}_{2}$ analysis. Buds were removed from plants by pruning shears. The cut was made $2 \mathrm{~cm}$ before the bud, and a piece of the branch was removed so as to prevent bud tissue oxidation and dehydration from taking place. Afterwards, buds were identified and stored in liquid nitrogen. After collection, buds were immediately taken to the laboratory and stored in a ULT freezer up to both analyses, about $30^{\text {th }}$ DAA.

Analyses of enzyme activity and $\mathrm{H}_{2} \mathrm{O}_{2}$ levels

Analyses of enzyme activity were determined when $300 \mathrm{mg}$ plant material (scaleless buds) was macerated in a chilled mortar with the use of liquid nitrogen, in the presence of polyvinylpolypyrrolidone (PVPP). It was homogenized in $2 \mathrm{~mL}$ extraction buffer composed of $100 \mathrm{mM}$ potassium phosphate (pH 7.8), $0.1 \mathrm{mM}$ EDTA and $10 \mathrm{mM}$ ascorbic acid. After centrifugation at $12,000 \mathrm{~g}$ for 20 minutes at $4^{\circ} \mathrm{C}$, the supernatant was collected. The resulting extract was used to quantify proteins on a spectrophotometer at $595 \mathrm{~nm}$ with the 
use of the Bradford method (1976) and to determine specific activities of antioxidant enzymes.

SOD activity was evaluated by its capacity to inhibit nitro blue tetrazolium (NBT) photoreduction (Giannopolitis and Ries, 1997). Evaluation was carried out in a reaction medium composed of potassium phosphate (100 mM, pH 7.8), methionine $(14 \mathrm{mM})$, EDTA $(0.1 \mu \mathrm{M})$, NBT $(75 \mu \mathrm{M})$ and riboflavin $(2 \mu \mathrm{M})$. Test tubes with reaction media and samples were illuminated for seven minutes using a 20W fluorescent lamp. Concerning the control, the same reaction medium, with no sample, was illuminated, while the blank was kept in the dark. Readings were carried out at $560 \mathrm{~nm}$. The enzyme was calculated by the equation: $\%$ inhibition $=(A 560$ sample with enzyme extract - A560 control with no enzyme)/(A560 control with no enzyme). A unit of SOD shows the amount of enzyme that is enough to inhibit $50 \%$ of NBT photoreduction in the assay.

CAT activity was evaluated using the protocol described by Azevedo et al. (1998). This activity was observed by a decrease in absorbance at $240 \mathrm{~nm}$ for two minutes in a reaction medium with the buffer potassium phosphate (100 $\mathrm{mM}, \mathrm{pH} 7.0$ ) and $\mathrm{H}_{2} \mathrm{O}_{2}(12.5 \mathrm{mM})$, incubated at $28^{\circ} \mathrm{C}$.

In order to determine APX activity, the methodology proposed by Nakano and Asada (1981) was used. Ascorbate oxidation rate was monitored at $290 \mathrm{~nm}$. The reaction was carried out in a medium composed of buffer potassium phosphate $(100 \mathrm{mM}, \mathrm{pH} 7.0)$ and ascorbic acid $(0.5 \mathrm{mM}$ and $\mathrm{H}_{2} \mathrm{O}_{2} \mathrm{O} .1 \mathrm{mM}$ ), incubated at 28 ․ C. A decrease in absorbance was observed for two minutes after the beginning of the reactions.

In the analysis of the $\mathrm{H}_{2} \mathrm{O}_{2}$ content, about $300 \mathrm{mg}$ buds was macerated in a chilled mortar with the use of liquid nitrogen. The extraction buffer was composed of trichloroacetic acid (TCA) at $0.1 \%$. The homogenate was centrifuged at $12,000 \mathrm{~g}$ for 20 minutes, and the supernatant was transferred to $2-\mathrm{mL}$ polypropylene test tubes. The methodology proposed by Velikova et al. (2000) was used. The reaction medium was composed of $0.7 \mathrm{~mL}$ potassium phosphate $10 \mathrm{mM}$ (pH 7.0), 1 $\mathrm{mL} \mathrm{KI} 1 \mathrm{M}$ and $0.25 \mathrm{~mL}$ supernatant. Test tubes were kept in a water bath for 10 minutes at $30^{\circ} \mathrm{C}$. Readings were carried out by a spectrophotometer at $390 \mathrm{~nm}$, and $\mathrm{H}_{2} \mathrm{O}_{2}$ concentration was expressed as $\mu \mathrm{mol} \mathrm{H}_{2} \mathrm{O}_{2} \mathrm{~g}^{-1} \mathrm{FM}$.

\section{Budbreak and blooming evaluation}

To evaluate budbreak and blooming, four branches per plant were marked. The one that had the largest number of lateral buds in the four quadrants of the plant was selected. Buds were counted in the selected branch when they were still dormant. Total numbers of sprouted buds were counted at $32 \mathrm{t}^{\mathrm{h}}, 40^{\text {th }}, 45^{\text {th }}$ and $52^{\text {th }}$ DAA of budbreak inducers to calculate the budbreak percentage, while the number of flower buds was counted to calculate the blooming percentage. The following equation can be applied to the total number of buds on a branch (including dormant buds) and the number of broken buds on every evaluation date $\left(32^{\text {th }}, 40^{\text {th }}, 45^{\text {th }}\right.$ and 52 th DAA): [(number of broken buds on the twig/total number of buds on the twig) x100]. The result of the equation represents budbreak percentage. To the total number of buds on a branch (including dormant buds) and the number of buds that had bloomed before every evaluation date $\left(32^{\text {th }}, 40^{\text {th }}, 45\right.$ th and 52 th DAA), the following equation was applied: [(number of blooming buds on the twig/total number of buds on the twig) x100]. The result of the equation represents blooming percentage.

\section{Statistical analyses}

Statistical analyses were carried out by the Statistical Analysis System (SAS Studio), and the analysis of variance (ANOVA) was conducted by the $\mathrm{F}$ Test. When data were significant, they were submitted to the Duncan's multiple range test at $5 \%$ significance. Values in percentages were transformed by the expression arc sen $\sqrt{\mathrm{x} / 100}$, where $\mathrm{x}$ is the value of replicates of every response variable. This transformation was carried out to meet the requirement of variance homogeneity proclaimed by the ANOVA, but results are shown in the original scale of variables.

\section{Conclusions}

SOD activity increases as dormancy stage ends, regardless of the treatment.

CAT activity is affected by the application of budbreak inducers.

When an efficient inducer is applied, the closer to the end of dormancy, the more CAT activity decreases.

The budbreak inducer composed of Erger $^{\circledR} 7 \%+$ calcium nitrate $5 \%$ is the one that has the best potential to be used in 'Castel Gala' apple trees.

\section{Acknowledgments}

The authors thank the Coordenação de Aperfeiçoamento de Pessoal de Nivel Superior (Capes) for providing funds for a scholarship.

\section{References}

Abreu ES, Carra B, Spagnol D, Schmitz JD, Silva TA, Hellwig CG, Fachinello JC (2018) Evaluation of the effect of different budbreak promoters on apple trees 'Eva' and 'Castel Gala' in mild winter climate conditions. J Exp Agric Int. 20(1):1-7.

Azarabadi S, Abdollahi H, Torabi M, Salehi Z, Nasiri J (2017) ROS generation, oxidative burst and dynamic expression profiles of ROS-scavenging enzymes of superoxide dismutase (SOD), catalase (CAT) and ascorbate peroxidase (APX) in response to Erwinia amylovora in pear (Pyrus communis L). Eur J Plant Pathol. 147(2):279-294.

Azevedo RA, Alas RM, Smith RJ, Lea PJ (1998) Response of antioxidant enzymes to transfer from elevated carbon dioxide to air and ozone fumigation, in the leaves and roots of wild-type and a catalase-deficient mutant of barley. Physiol Plantarum. 104(2):280-292.

Bradford MM (1976) A rapid and sensitive method for the quantitation of microgram quantities of protein utilizing the principle of protein-dye binding. Anal Biochem. 72(12):248-254.

Cai B, Wang H, Liu T, Zhuang W, Wang Z, Qu S, Qin Y. (2019) Effects of gibberellins $A_{4}$ on budbreak, antioxidant enzymes' activity and proline content of flower buds in sweet cherry (Prunus avium). Acta Physiol Plant. 41(6):88-97.

Darde DC, Almeida GK, Marodin GAB (2019) Budburst and flowering intensity by the spraying of dormancy-breaking products in 'Eva'apple trees. Semin-Cienc Agrar. 40(3):1049-1062.

Dousseau S, Rodrigues AC, Lira JMS, Ribeiro Júnior PM, Pacheco FV, Alvarenga AAD, Resende MLV, De Paula ACCFF (2016) Aplicação exógena de quitosana no sistema antioxidante de jaborandi. Cienc rural, 46(1):191-197.

El-Yazal MAS, Rady MM (2014) Exogenous onion extract hastens bud break, positively alters enzyme activity, hormone, amino acids and phenol contents, and improves fruit quality in 'Anna' apple trees. Sci Hortic-Amsterdam. 169:154-160. 
Farrokhi J, Darvishzadeh R, Naseri L, Azar MM, Maleki HH (2011) Evaluation of Genetic Diversity Among Iranian Apple ('Malus domestica' Borkh.) Cultivars and Landraces Using Simple Sequence Repeat Markers. Aust J Crop Sci. 5(7):815821.

Giannopolitis CN, Ries SK (1997) Superoxide dismutases. I. Occurrence in higher plants. Plant Physiol. 59(2):309-314.

Hernandez JA, Díaz-Vivancos P, Martínez-Sánchez G, Alburquerque N, Martínez D, Barba-Espín G, Acosta-Motos JR, Carrera E, García-Bruntón J (2021) Physiological and biochemical characterization of bud dormancy: Evolution of carbohydrate and antioxidant metabolisms and hormonal profile in a low chill peach variety. Sci Hortic-Amsterdam. 281:109957.

Margoti G, Dagostin L, Fowler JG, Biasi LA (2020) Erger $^{\circledR} \mathrm{e}$ nitrato de cálcio na superação da dormência da macieira 'Eva'. Global Sci Technol. 13(1):161-170.

Mohamed HB, Vadel AM, Geuns JM, Khemira H (2012) Effects of hydrogen cyanamide on antioxidant enzymes' activity, proline and polyamine contents during bud dormancy release in Superior Seedless grapevine buds. Acta Physiol Plant. 34(2):429-437.

Mujahid Z, Tounekti T, Khemira H (2020) Cold plasma treatment to release dormancy and improve growth in grape buds: a promising alternative to natural chilling and rest breaking chemicals. Sci Rep-UK. 10(1):1-10.

Nakano Y, Asada K (1981) Hydrogen peroxide is scavenged by ascorbate-specific peroxidases in spinach chloroplasts. Plant Cell Physiol. 22(5):867-880.

Pasa MDS, Felippeto J, Nava G, Silva CPD, Brighenti AF, Ciotta MN (2018) Performance of 'Fuji Suprema' apple trees treated with budbreak promoters, in São Joaquim-SC. Rev Bras Frutic. 40(1):e-325.
Pérez FJ, Lira W (2005) Possible role of catalase in postdormancy bud break in grapevines. J Plant Physiol 162(3):301-308.

Rady MM, El-Yazal MAS (2013) Response of 'Anna' apple dormant buds and carbohydrate metabolism during floral bud break to onion extract. Sci Hortic-Amsterdam. 155:7884.

Santos RFD, Marques LOD, Mello-Farias P, Martins CR, Konzen $\mathrm{LH}$, Carvalho IR, Malgarim MB (2020) Budbreak induction in kiwifruit vines cultivated in an organic system by the biological method of single node cutting. Bragantia. 79(2):260-267.

Shalimu D, Sun J, Baskin CC, Baskin JM, Sun L, Liu Y (2016) Changes in oxidative patterns during dormancy break by warm and cold stratification in seeds of an edible fruit tree. AoB Plants. 8.

Takemura Y, Kuroki K, Jiang M, Matsumoto K, Tamura $F$ (2015) Identification of the expressed protein and the impact of change in ascorbate peroxidase activity related to endodormancy breaking in Pyrus pyrifolia. Plant Physiol Bioch. 86:121-129.

Velikova V, Yordanov I, Edreva A (2000) Oxidative stress and some antioxidant systems in acid rain-treated bean plants. Protective role of exogenous polyamines. Plant Sci. 151(1):59-66.

Vuleta A, Jovanović SM, Tucić B (2016) Adaptive flexibility of enzymatic antioxidants SOD, APX and CAT to high light stress: The clonal perennial monocot Iris pumila as a study case. Plant Physiol Bioch. 100:166-173.

Xing-Liang L, Jun-Ke Z, Min-Ji L, Bei-Bei Z, Qiang Z, Qin-Ping W (2017) Genome-wide analysis of antioxidant enzyme gene families involved in drought and low-temperature responses in Apple (Malus domestica). J Hortic Sci Biotechnol. 93(4):337-346. 